\title{
Effects of the chemokine CXCL12 and combined internalization of its receptors CXCR4 and CXCR7 in human MCF-7 breast cancer cells
}

\author{
Kirsten Hattermann • Eric Holzenburg • Friederike Hans • \\ Ralph Lucius • Janka Held-Feindt • Rolf Mentlein
}

Received: 13 November 2013 / Accepted: 20 January 2014 / Published online: 26 April 2014

(C) The Author(s) 2014. This article is published with open access at Springerlink.com

\begin{abstract}
The chemokine CXCL12 (stromal cell-derived factor-1, SDF-1) and its receptor CXCR4 play a major role in tumor initiation, promotion, progression and metastasis, especially for breast cancer cells. Recently, CXCR7 has been identified as a second receptor for CXCL12; nevertheless, it also binds CXCL11 (interferon-inducible T cell $\alpha$ chemoattractant, I-TAC). However, little is known about the co-expression of the two receptors and their interactions. Quantitative reverse transcription plus the polymerase chain reaction has demonstrated that both receptors are frequently co-expressed in breast cancer cell lines, whereas other tumor cell lines often express only one of them. For interaction studies, we chose MCF-7 breast cancer cells, since they highly express CXCR4 and CXCR7 at the protein level but not CXCR3 (another target for CXCL11). Immunofluorescence and gold-labeling by light and electron microscopy, respectively, revealed that both receptors were localized at the cell surface in non-stimulated cells. After exposure to CXCL12 or CXCL11, the receptors were rapidly internalized alone or in close proximity. Stimulation with the CXCR4- or CXCR7-selective non-peptide antagonists
\end{abstract}

Kirsten Hattermann and Eric Holzenburg contributed equally to the experiments.

This work was supported by the Deutsche Forschungsgemeinschaft (ME 758/10-1 and HE3400/5-1).

Electronic supplementary material The online version of this article (doi:10.1007/s00441-014-1823-y) contains supplementary material, which is available to authorized users.

K. Hattermann · E. Holzenburg $\cdot$ F. Hans $\cdot$ R. Lucius $\cdot$

R. Mentlein $(\triangle)$

Department of Anatomy, University of Kiel, Olshausenstraße 40,

24098 Kiel, Germany

e-mail: rment@anat.uni-kiel.de

J. Held-Feindt

Department of Neurosurgery, University Medical Center

Schleswig-Holstein UKSH, Campus Kiel, 24105 Kiel, Germany
AMD3100 and CCX733 resulted not only in single internalization but partly also in co-internalization of the two receptors. Furthermore, both chemokine ligands reduced staurosporineinduced apoptosis and caspase-3/7 activation; however, the selective inhibitors merely had partial inhibitory effects on these biological responses. Our findings suggest that CXCR4 and CXCR7 closely interact in breast cancer cells. Both are co-internalized, transduce signals and induce further biological effects partly independently of a selective stimulus or antagonist.

Keywords Chemokine receptor · Breast cancer · Internalization $\cdot$ Signal transduction $\cdot$ Apoptosis

$\begin{array}{ll}\text { Abbreviations } & \\ \text { AMC } & \text { 7-Amino-4-methylcoumarine } \\ \text { BSA } & \begin{array}{l}\text { Bovine serum albumin } \\ \text { Interferon-inducible T cell } \alpha \\ \text { chemoattractant }\end{array} \\ \text { CXCL12 or SDF-1 } & \begin{array}{l}\text { Stromal cell-derived factor-1 } \\ \text { 4',6-Diamidino-2-phenylindole }\end{array} \\ \text { DAPI } & \text { Dulbecco's modified Eagle's medium } \\ \text { DMEM } & \text { Dimethylsulfoxide } \\ \text { DMSO } & \text { Epidermal growth factor } \\ \text { EGF } & \text { Enzyme-linked immunoassay } \\ \text { ELISA } & \text { Extracellular-signal-regulated kinases } \\ \text { Erk } & \text { (p42/p44) } \\ \text { FCS } & \text { Fetal calf serum } \\ \text { GAPDH } & \text { Glyceraldehyde 3-phosphate } \\ \text { dehydrogenase } \\ \text { PBS } & \text { Phosphate-buffered saline } \\ \text { P/S } & \text { Penicillin/streptomycin } \\ \text { RT-PCR } & \text { Reverse transcription plus the } \\ \text { WGA } & \text { polymerase chain reaction } \\ \text { Wheat germ agglutinin }\end{array}$




\section{Introduction}

Chemokines were initially discovered as small, 8- to $10-\mathrm{kDa}$ chemotactic cytokines in the immune system; they attract leukocytes by interacting with their G-protein-coupled seven-transmembrane domain receptors. Later, chemokines and their receptors were shown to exhibit a much broader function in tissue development and homeostasis and in many pathological conditions (for a review, see Mentlein et al. 2013). In particular, they play decisive roles in tumor initiation, promotion, progression and metastasis (for a review, see Zlotnik et al. 2011). With respect to the last-mentioned, the chemokine CXCL12/SDF-1 (stromal cell-derived factor-1) and its receptor CXCR4 have attracted great interest as they direct CXCR4-expressing breast cancer cells to peripheral tissues such as lung, liver, lymph nodes and bone marrow where the ligand CXCL12 is constitutively produced (Müller et al. 2001). However, the interactions and regulations of chemokines and their receptors are highly complex and also in this case, the initially simple model has had to be modified (for a review, see Hattermann and Mentlein 2013). Namely, a second receptor for CXCL12 was recently de-orphanized and named CXCR7/RDC1 (Balabanian et al. 2005; Burns et al. 2006). In addition to CXCL12, CXCR7 binds with ten-fold lower affinity to CXCL11/I-TAC (interferon-inducible T cell $\alpha$ chemoattractant), which is also a ligand for CXCR3 (which is targeted also by CXCL9/Mig and CXCL10/IP-10).

At first, CXCR7 was thought to be merely a non-signaling decoy or scavenger receptor, since because of alterations in a conserved DRYLAIV-motif, it fails to couple to G-proteins (Naumann et al. 2010; Thelen and Thelen 2008) and does not cause $\mathrm{Ca}^{2+}$ mobilization upon activation, as is known for most chemokine receptors (Burns et al. 2006). However, recent reports show that CXCR7 signals alternatively through $\beta$ arrestin (Rajagopal et al. 2010) and thus directly mediates several cellular effects, in addition to its function in controlling extracellular CXCL12 levels. In cells expressing solely CXCR7, stimulation by CXCL12 or CXCL11 results in the phosphorylation of the kinases Erk (extracellular-signal regulated kinases (p42/p44)) and Akt, for example, in human leukocytes, vascular smooth muscle, rat glial, or human glioblastoma cells (Balabanian et al. 2005; Rajagopal et al. 2010; Hattermann et al. 2010; Ödemis et al. 2012). Regarding cellular responses, CXCR7 stimulation enhances cell survival of tumor cells, e.g., by reduction of temozolomide-induced apoptosis in glioblastoma cells or of cell adhesion (Burns et al. 2006; Miao et al. 2007; Hattermann et al. 2010, 2012).

However, some cell types, especially endothelial and distinct tumor cells, express the two CXCL12-receptors, CXCR4 and CXCR7, in combination (Miao et al. 2007; Heinrich et al. 2012) and they may regulate one another's function. This can be studied by use of selective antagonists, by application of CXCL11 (if CXCR3 is absent), or by silencing/overexpression. Here, partially divergent reports exist. For example, CXCR7-activation can block CXCR4driven transendothelial migration of lymphoma cells (Zabel et al. 2009), can impair CXCL12-induced tube formation of endothelial progenitor cells (Yan et al. 2012), facilitate CXCR4-mediated neuronal migration (Sanchez-Alcaniz et al. 2011) and enhance CXCR4-promoted chemotaxis in vitro but decreases matrix degradation and invasion in vivo in CXCR4-overexpressing MTLn3 breast cancer cells (Herandez et al. 2011). Indeed, CXCR4-CXCR7 heterodimerization has been recently observed by biochemical methods in transfected HEK cells (Levoye et al. 2009; Décaillot et al. 2011) and the ligand CXCL12 might also homodimerize even at low concentrations (Ray et al. 2012a).

Thus, cellular responses to CXCL12 (and CXCL11) might depend on the relative expression of the two receptors or on the cell type. Therefore, more clarification of their interactions is urgently required. Since breast cancer cells are an important target, we examined the expression of CXCR4 and CXCR7 in various cell lines and selected MCF-7 cancer cells as a representative that expresses both receptors at comparable levels but not CXCR3. We investigated the localization of CXCR4 and CXCR7, before and after chemokine-stimulation of these cells, by fluorescence and electron microscopy and evaluated the influence of receptor-selective antagonists on CXCL12/CXCL11-mediated signal transduction and its effects.

\section{Materials and methods}

Peptides and inhibitors

Recombinant human chemokines and growth factors were from Pepro Tech (Rocky Hill, N.J., USA; CXCL11) or Immunotools (Friesoythe, Germany; CXCL12, epidermal growth factor). Staurosporine was purchased from Calbiochem (Merck-Calbiochem, Darmstadt, Germany). The non-peptide antagonist AMD3100 (= plerixafor, Mozobil, selective for CXCR4) was obtained from Sigma-Aldrich (St. Louis, Mo., USA) and CCX733 (selective for CXCR7) was a generous gift from Mark E.T. Penfold from ChemoCentryx (Mountain View, Calif., USA). Staurosporine and antagonists were dissolved in dimethylsulfoxide and diluted from these stock solutions.

Cell cultures and stimulations

MCF-7 mamma carcinoma cells were obtained from the American Type Culture Collection (ATTC) via Cell Line Service, Eppelheim, Germany and cultured in Dulbecco's modified Eagle's medium (DMEM) supplemented with $10 \%$ fetal calf serum (FCS) and $1 \%$ penicillin/streptomycin 
(P/S; all from PAN Biotech, Aidenbach, Germany); other mamma carcinoma cell lines (T47D, BT549, MDA-MB231) were obtained and kept as described elsewhere (Stark et al. 2007). The glioma cell line U343 was obtained from the Deutsches Krebsforschungszentrum (Heidelberg, Germany; cf. Mentlein and Held-Feindt 2002), cultivated in $10 \%$ $\mathrm{DMEM}+10 \% \mathrm{FCS}+1 \% \mathrm{P} / \mathrm{S}$; melanoma cells (LOX, Mel6, Mel Juso), small cell lung cancer cells (OH1, OH2 and SW2) and the neuroblastoma cell line SH-SY5Y were generously supplied by Prof. Dr. Udo Schumacher (Department of Anatomy, University of Hamburg, Germany) and characterized and cultivated as described (Thies et al. 2007; Lange et al. 2011). All cells were routinely checked for Mycoplasma contamination by 4',6-diamidino-2-phenylindole (DAPI) staining and Mycoplasma-specific polymerase chain reaction (PCR; Minerva Biolabs, Berlin, Germany).

\section{Quantitative reverse transcription plus PCR}

RNA was isolated with the Qiazol Lysis reagent (Qiagen, Hilden, Germany) and digested by DNase. cDNA was synthesized and real-time reverse transcription plus PCR (RT-PCR) was performed (Ludwig et al. 2005) by using the following TaqMan primer probes (Applied Biosystems, Foster City, Calif., USA): human glyceraldehyde 3-phosphate dehydrogenase (hGAPDH; Hs99999905_m1), hCXCL11 (Hs00171138_m1), hCXCL12 (Hs00171022_m1), hCXCR3 (Hs00171041_m1), hCXCR4 (Hs00607978_s1) and hCXCR7 (Hs00664172_s1). Cycles of thresholds (CT) were determined with an $\mathrm{ABI}$ PRISM 7000 sequence detection system and $\Delta \mathrm{CT}$ values $=\mathrm{CT}_{\text {Gene of interest }}-\mathrm{CT}_{\mathrm{GAPDH}}$ were calculated. A $\Delta \mathrm{CT}$ value of 3.33 corresponds to one magnitude lower gene expression compared with GAPDH. For each gene, logarithmic linear dependence of CT-values from the numbers of copies was verified by using various amounts of cDNA.

Western blotting and enzyme-linked immunoassay

Western blot experiments were performed as previously described (Hattermann et al. 2008). CXCR7 was detected with anti-CXCR7 (ab 38089, rabbit, 1:500; Abcam, Cambridge, Mass., USA); re-blotting was performed with anti-caveolin-1 (N-20, rabbit, 1:200; Santa Cruz Biotechnology, Santa Cruz, Calif., USA). For analysis of kinase phosphorylation, blots were incubated with anti-phosphorylated Erk (pErk1/2; Thr202/Tyr204; 1:500; Cell Signaling Technology, Danvers, Mass., USA) and re-probed after stripping with methanol and $0.1 \mathrm{~mol} / \mathrm{l}$ glycine/ $\mathrm{HCl}$ buffer, $\mathrm{pH}$ 2.5, with anti-Erk2 (1:500; Santa Cruz).

Enzyme-linked immunoassay (ELISA) for CXCL12 was performed with culture supernatants and standards, with recombinant protein being applied to Nunc Maxisorb 48-well plates (Nunc, Roskilde, Denmark) for $2 \mathrm{~h}$ at room temperature. After removal of samples, wells were blocked with $1 \%$ bovine serum albumin (BSA) and $0.02 \%$ Tween in phosphate-buffered saline (PBS) for $1 \mathrm{~h}$, washed three times with PBS at pH 7.4, incubated with anti-CXCL12 (1:500; anti-SDF $\alpha$, rabbit polyclonal, ab9797, Abcam), washed with PBS $(3 \times)$, incubated with horseradish-peroxidase-labeled anti-rabbit $\operatorname{IgG}(1: 1000$, raised in goats, sc2030, Santa Cruz Biotechnology), washed $(3 \times)$ and finally exposed to $100 \mu \mathrm{l}$ 3,3',5,5'-tetramethylbenzidine substrate (Thermo Scientific Pierce, Waltham, Mass., USA), the reaction being stopped with $50 \mu \mathrm{l} 0.5 \mathrm{M} \mathrm{H}_{2} \mathrm{SO}_{4}$. Extinction at $450 \mathrm{~nm}$ was measured against a reference wavelength $(620 \mathrm{~nm})$.

Internalization experiments and fluorescence light and electron microscopy

Subconfluent cells were grown on poly-D-lysine-coated coverslips in DMEM plus $10 \%$ FCS for 1 day, washed with PBS plus $0.5 \%$ BSA and equilibrated twice $(1 \mathrm{~h}$ each) with DMEM plus $0.5 \%$ fatty-acid-free BSA (Sigma-Aldrich). The cells were then gradually cooled to $4{ }^{\circ} \mathrm{C}$ and exposed (at $4{ }^{\circ} \mathrm{C}$ ) to primary antibodies (for fluorescence light microscopy: rabbit anti-CXCR4, 1:100, Imgenex IMG-125, San Diego, Calif., USA; for electron microscopy: goat antiCXCR4, 1:100, Abcam ab1671; fluorescence light and electron microscopy: mouse anti-CXCR7, 1:100, Chemocentrxy 11G8) for 45 min at $4{ }^{\circ} \mathrm{C}$. For secondary antibody controls, primary antibodies were omitted. After being washed, cells were then incubated in the same medium with secondary antibodies for $45 \mathrm{~min}$ at $4{ }^{\circ} \mathrm{C}$. For light microscopy, AlexaFluor-labeled donkey anti-mouse $\operatorname{IgG} 488$ and donkey antirabbit IgG 555 (1:800 each; Invitrogen, Carlsbad, Calif.) were applied as secondary antibodies. For electron microscopy, colloidal-gold-labeled donkey anti-goat IgG with $15-\mathrm{nm}$ gold (Aurion, Wageningen, The Netherlands) and, after several rinses, goat anti-mouse IgG (British BioCell, Cardiff, UK) conjugated to 5 -nm gold were used as secondary antibodies. After two washes, medium was replaced with fresh medium $\left(4{ }^{\circ} \mathrm{C}\right)$ containing ligands or antagonists. Cells were then warmed to $37{ }^{\circ} \mathrm{C}$ for various times (or left at $4{ }^{\circ} \mathrm{C}$ as controls) and fixed with Zamboni's fixative consisting of $4 \%$ formaldehyde freshly prepared from paraformaldehyde with $17.5 \%$ saturated picrinic acid in phosphate buffer for fluorescence microscopy or with $4 \%$ formaldehyde freshly prepared from paraformaldehyde and $0.5 \%$ glutaraldehyde in PBS for electron microscopy. For fluorescence light microscopy, fixed cells were washed with PBS, incubated with Alexa-Fluor647-labeled wheat germ agglutinin (WGA, 1:200, $10 \mathrm{~min}$; Invitrogen), counterstained with DAPI and inspected with a Zeiss Axiovert $200 \mathrm{M}$ microscope with ApoTome. Measurements of cytosolic:surface ratio were performed as described in Supplementary Fig. 1. For electron microscopy, specimens were washed with PBS, exposed to $2 \%$ osmium 
tetroxide for $30 \mathrm{~min}$, dehydrated in series with increasing ethanol concentrations and embedded in Araldite. Ultrathin $(60 \mathrm{~nm})$ sections were cut, contrasted in saturated uranyl acetate for $2 \mathrm{~min}$ and viewed under a Zeiss 902 electron microscope at a primary magnification of $\times 50,000$ (cf. Krisch et al. 1998).

\section{Apoptosis and caspase assays}

Cell death assays were performed in DMEM plus $0.2 \%$ FCS for the indicated times. For detection of nuclei with signs of apoptosis, namely nuclear fragmentation and/or chromatin condensation, cells were seeded on poly-D-lysine-coated coverslips, grown overnight and then treated with staurosporine, chemokines and antagonists for $24 \mathrm{~h}$. After being rinsed with PBS, cells were fixed with ice-cold acetone/methanol (1:1; $10 \mathrm{~min})$ and washed $(3 \times)$ with PBS. Nuclei were stained with DAPI for $30 \mathrm{~min}$ (modified after Nicoletti et al. 1991). Damaged nuclei were evaluated and counted by a nonbiased person.

Caspase-3/7 activity was measured after an 8 -h exposure to toxic agents and chemokines by collecting adherent and nonadherent cells by centrifugation for $5 \mathrm{~min}$ at $1000 \mathrm{~g}$, washes with PBS and lysis in 100-200 $\mu 10.1 \%$ Nonidet P40 (NP40), $10 \mathrm{mM}$ dithiothreitol, $1 \mathrm{mM}$ EDTA, $100 \mathrm{mM} \mathrm{NaCl}$ in $50 \mathrm{mM}$ HEPES buffer, $\mathrm{pH}$ 7.4. After a freeze-thaw cycle (30 $\mathrm{min}$ at $70^{\circ} \mathrm{C}$ ) and protein determination of an aliquot by the Bradford assay, samples were adjusted to equal protein concentrations and volumes $(50 \mu \mathrm{g}$ protein $/ 250 \mu \mathrm{l})$ and incubated with $250 \mu \mathrm{l} 40 \mu \mathrm{M}$ N-Ac-Asp-Glu-Val-Asp-AMC (Ac-DEVDAMC; Bachem, Torrance, Calif., USA; AMC, 7-amino-4methylcoumarine) in lysis buffer at $37{ }^{\circ} \mathrm{C}$. Fluorescence of liberated AMC was determined after various times $\left(\lambda_{\mathrm{Ex}}=360 \mathrm{~nm} ; \lambda_{\mathrm{Em}}=460 \mathrm{~nm}\right)$ and the maximum value was set as $100 \%$. Controls were performed with identical incubations in the presence of $0.6 \mathrm{nM} \mathrm{N}$-Ac-Asp-Glu-Val-Asp-aldehyde (Ac-DEVD-CHO), a potent and selective inhibitor of caspases-3/7 and subtracted from the values.

\section{Statistical analysis}

Values are given as means \pm standard deviations (SD). Statistical significance was analyzed by a paired two-tailed Student's $t$-test; $* P<0.05,{ }^{* *} P<0.01,{ }^{* * *} P<0.001$.

\section{Results}

CXCR4 and CXCR7 are both expressed and produced by breast cancer cells

In an initial experiment, we investigated the expression of the chemokine receptors CXCR7 and CXCR4 in various breast cancer and other tumor cell lines by quantitative RT-PCR and Western blots (Fig. 1). Whereas the investigated breast cancer cells mostly transcribed (at different levels) both receptors, other tumor cell lines tested displayed a more restricted or no detectable expression (Fig. 1a). CXCR7 is prominent in human glioma cell lines such as U343 or A772 cells, as previously reported (Hattermann et al. 2010; with more examples). In contrast, the small cell lung cancer cell lines $\mathrm{OH} 1, \mathrm{OH} 2$ and SW2 transcribed all CXCR4 but were CXCR7negative. Among melanoma cell lines, some were negative for both receptors; others showed expression of the one or other receptor. The frequently used neuroblastoma cell line SH-SY5Y showed a relative high CXCR4 mRNA level but was CXCR7-negative. Hence, many but not all types of cancer cells express CXCR4 or CXCR7 in various combinations.

Since MCF-7 cells are established mamma carcinoma cells and transcribe both chemokine receptors at comparably high levels, we selected this cell line in order to study their interaction in an exemplary cell line. Receptor production at the protein level was verified by Western blot (Fig. 1c) and by immunocytochemistry (Fig. 2). Quantitative RT-PCR confirmed the absence of CXCR3, a competing receptor for CXCL11 and demonstrated a moderate production of the ligands CXCL11 and CXCL12 (Fig. 1b). To evaluate self-stimulation effects, endogenously produced CXCL12 was determined by ELISA of culture supernatants. After $24 \mathrm{~h}$ in culture, 500,000 MCF-7 cells produced $187 \pm 7 \mathrm{ng}$ CXCL12 (in $1 \mathrm{ml}$ medium, $n=3 \pm$ S.D.) yielding a concentration of about $23 \pm 1 \mathrm{nM}$. However, in most experiments, much lower cell numbers and incubations times were employed ensuring a much lower concentration during stimulations (less than $0.1 \mathrm{nM}$ ). Furthermore, cells were carefully washed prior to experiments in order to exclude self-stimulation and to ensure the recovery of internalized receptors.

CXCR4 and CXCR7 are jointly internalized upon ligand or antagonist stimulation

On living cells, receptors can be labeled at $4{ }^{\circ} \mathrm{C}$ by antibodies directed against their extracellular domains and visualized by use of differently fluorescent-labeled or gold-labeled secondary antibodies by using fluorescence or electron microscopy, respectively. On resting cells, both receptors can be readily stained at the cell surface by fluorescence (Figs. 2 and 3) and electron (Fig. 4) immunocytochemistry. As seen in the merged images of fluorescence by light microscopy or directly with the gold particles by electron microscopy, receptors are located separately and in close association. 

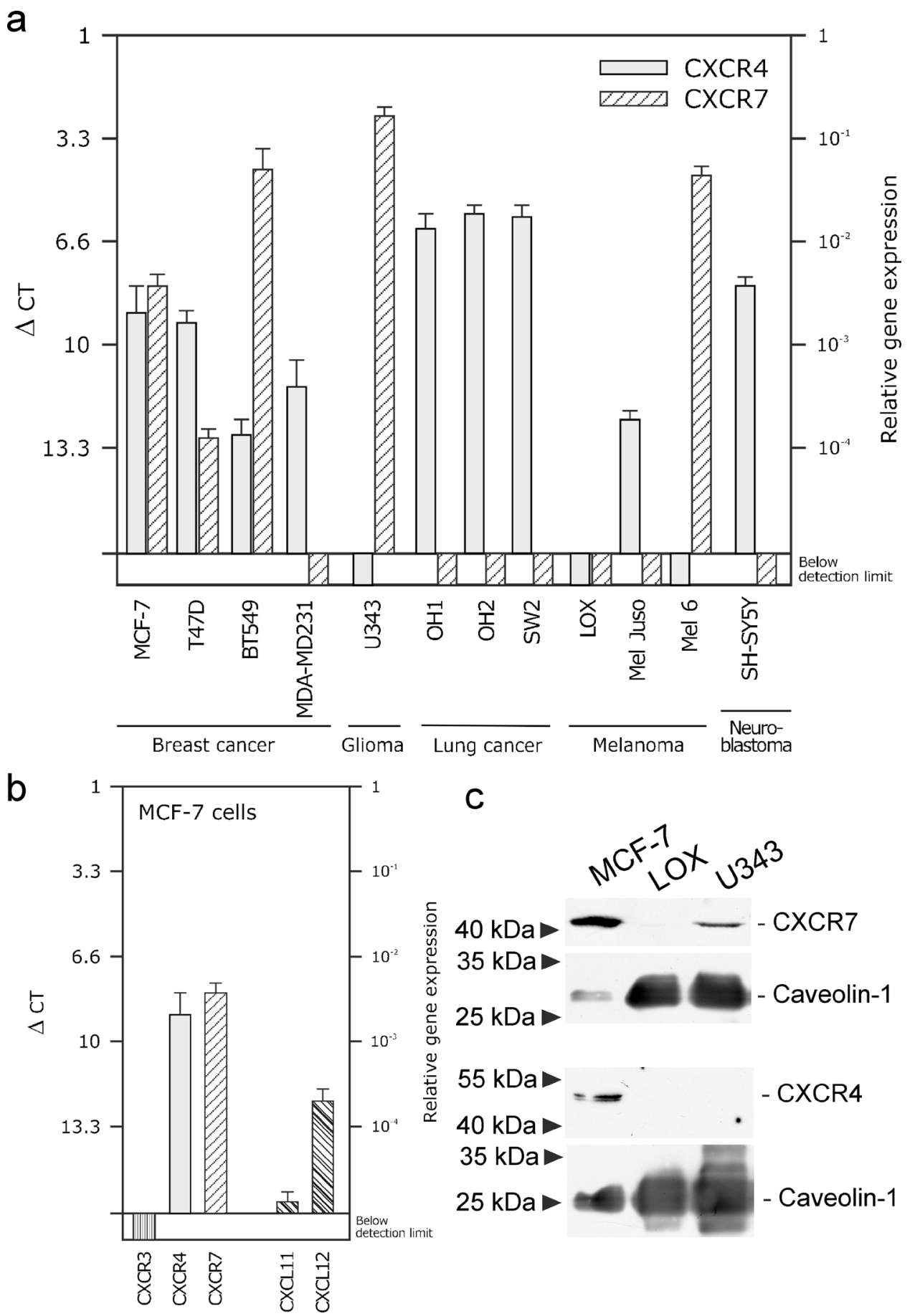

Fig. 1 Expression of chemokine receptors in MCF-7 and other tumor cells of various origin. a Transcription of chemokine receptors CXCR4 and CXCR7 in various types of tumor cells was determined by quantitative reverse transcription plus the polymerase chain reaction (RT-PCR). $\triangle \mathrm{CT}$ values relatve to glyceraldehyde 3-phosphate dehydrogenase (GAPDH) are given $(n=3 \pm$ S.D. $) ; \Delta \mathrm{CT}=3.33$ corresponds to one magnitude. Breast cancer cell lines show various levels of CXCR4 and CXCR7 transcription; mostly, both receptors are co-expressed. In contrast to mamma carcinoma cells, glioma cells (U343) exhibit a preferential CXCR7 expression (for more data, see Hattermann et al. 2010), whereas small cell lung cancer cells $(\mathrm{OH} 1, \mathrm{OH} 2, \mathrm{SW})$ and the neuroblastoma cell line $(\mathrm{SH}-\mathrm{SY} 5 \mathrm{Y})$ transcribe only CXCR4. In melanoma cell lines, both receptors are either not detectable $(L O X)$ or singularly transcribed (in $\mathrm{Mel}$

Juso, only CXCR4; in Mel6, only CXCR7). b Transcription of chemokine ligands and receptors in MCF-7 breast cancer cells as determined by quantitative RT-PCR (qRT-PCR; see a). CXCR4 and CXCR7 are both transcribed but not CXCR3 (but primers/probe yield a signal with $\mathrm{T}$ cells as positive controls, not shown). Moreover, the CXCR4/7 ligand CXCL12 is expressed at a low level, whereas the CXCR3/7 ligand CXCL11 is just above the detection limit. $\mathbf{c}$ Western blots of chemokine receptors CXCR4 and CXCR7 in membrane fractions of various types of human tumor cells clearly reveal a dual production of CXCR4 and CXCR7 in MCF-7 breast cancer cells, a single expression of CXCR7 in U343 glioma cells and an absence of both receptors in LOX melanoma cells, as also found by qRT-PCR (caveolin-1: loading control) 

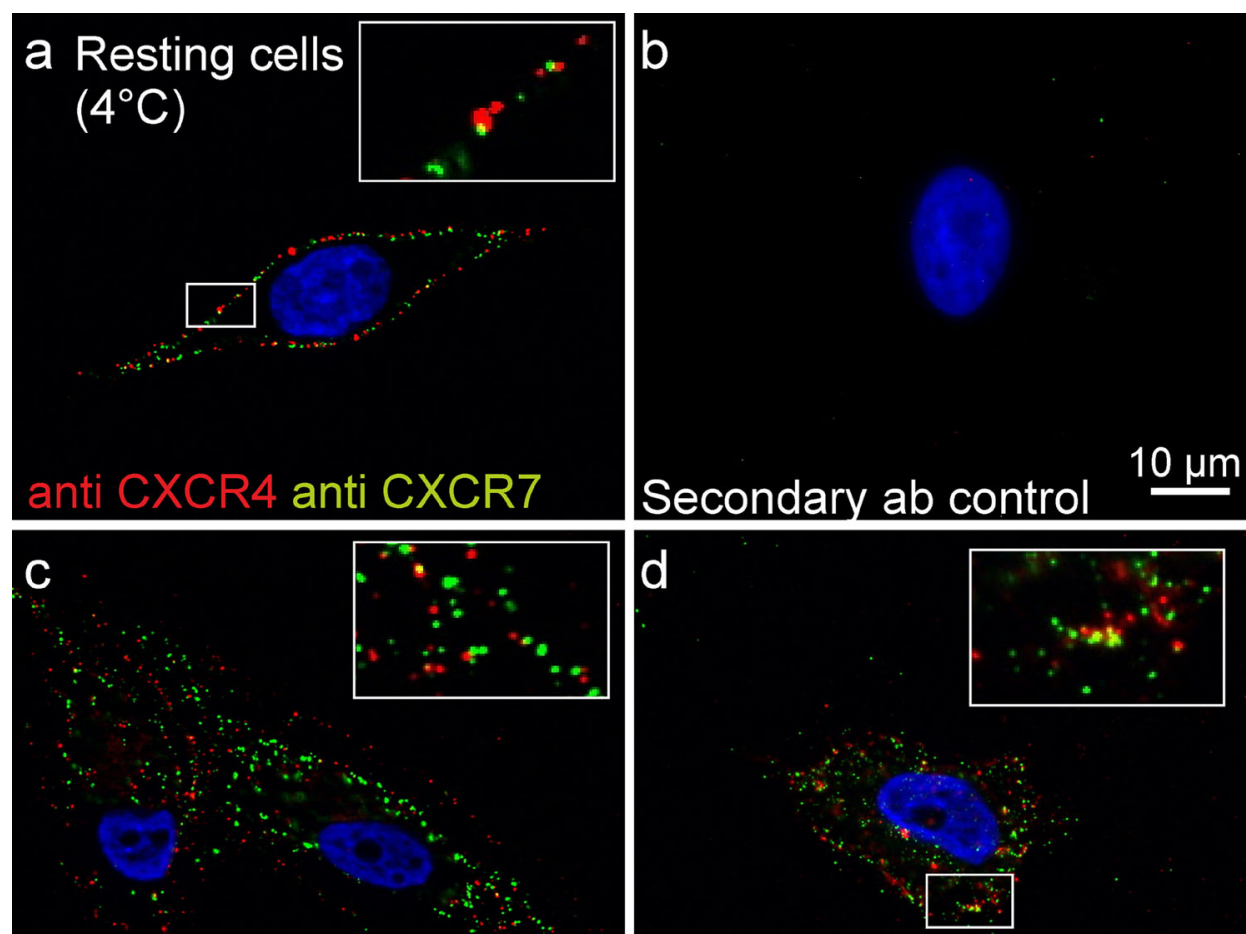

\section{$10 \mathrm{nM}$ CXCL12 - $5 \mathrm{~min}$}
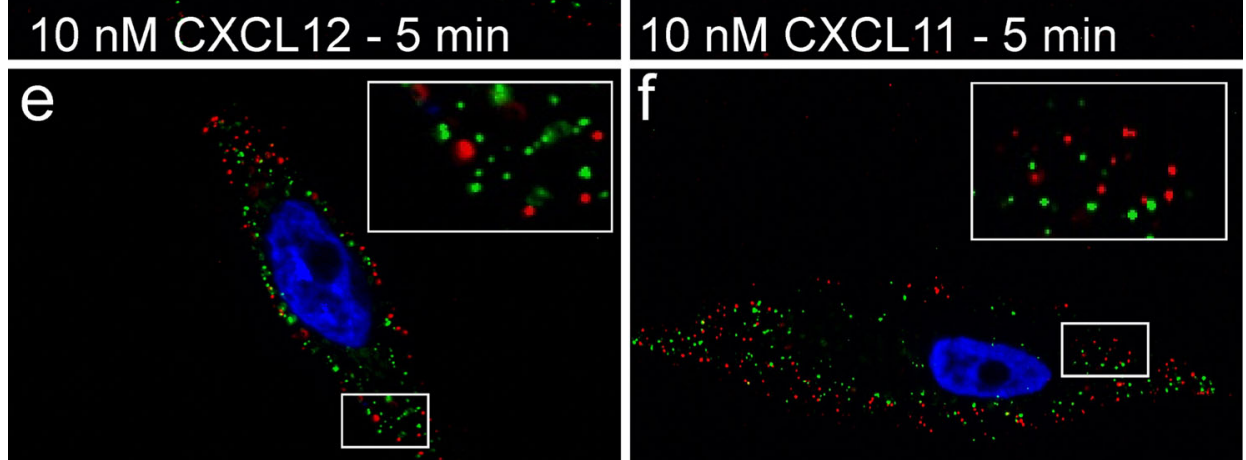

\section{0 nM CXCL12 - 10 min}
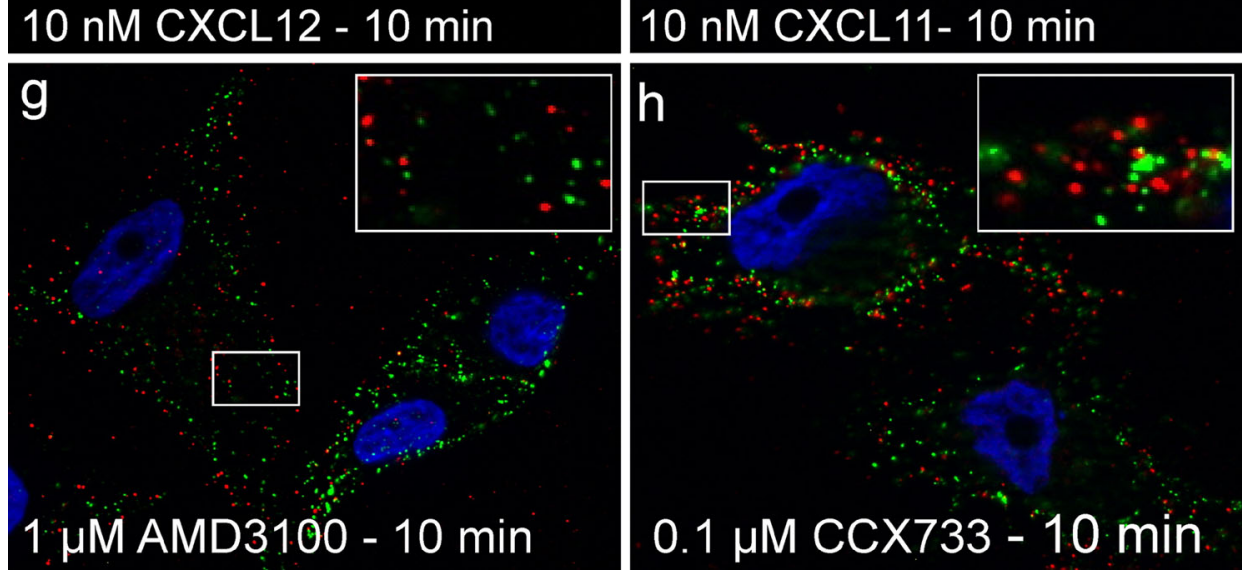

Fig. 2 Internalization of chemokine receptors CXCR4 and CXCR7 into MCF-7 cells upon stimulation with various ligands, as visualized by immuno-fluorescence light microscopy. a Chemokine receptors were immuno-labeled at $4{ }^{\circ} \mathrm{C}$ with red (CXCR4) and green (CXCR7) fluorescent (secondary) antibodies in resting cells. Without stimulation, receptors were scattered alone or lay in close proximity at the cell surface. b For

secondary antibody controls, primary antibodies were omitted. c-h Internalization was induced by stimulation with various ligands at various times at $37{ }^{\circ} \mathrm{C}$. After exposure to chemokines CXCL12 $(10 \mathrm{nM} ; \mathbf{c}, \mathbf{e})$ or CXCL11 (10 nM; d, f) or to non-peptide receptor-selective antagonists AMD3100 $(1 \mu \mathrm{M} ; \mathbf{g})$ or CCX733 $(0.1 \mu \mathrm{M}$; h) receptors were rapidly internalized mostly or partly together (see also inserts) 


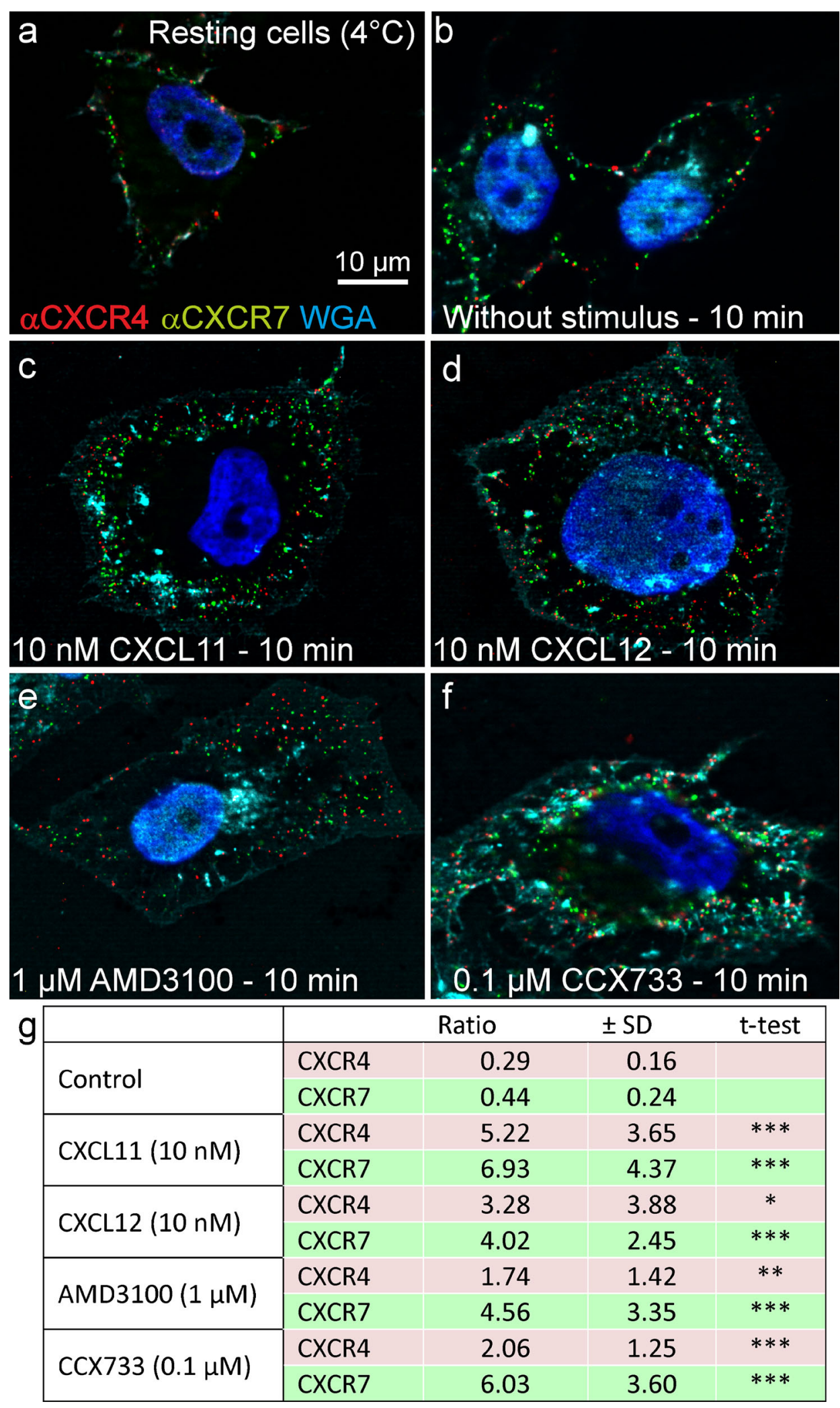

Fig. 3 Measurement of CXCR4 and CXCR7 localization. a-f Chemokine receptors were immuno-stained and internalization was induced by stimulation at $37{ }^{\circ} \mathrm{C}$ (cf. Fig. 2). Membranes were stained with AlexaFluor-647-labeled wheat germ agglutinin (WGA, here displayed in cyan). g Based on the membrane signal, the intensity of CXCR4 and CXCR7 signals was measured, yielding the cytosolic:surface ratio (means $\pm \mathrm{SD}$ ).
Unstimulated cells yielded low ratios (most receptors were on the surface), whereas both chemokines and synthetic antagonists yielded high ratios (most receptors were found intracellularly). For each stimulus, at least 10 cells were analyzed from two independent experiments (the quantification method is depicted in Supplementary Fig. 1) 

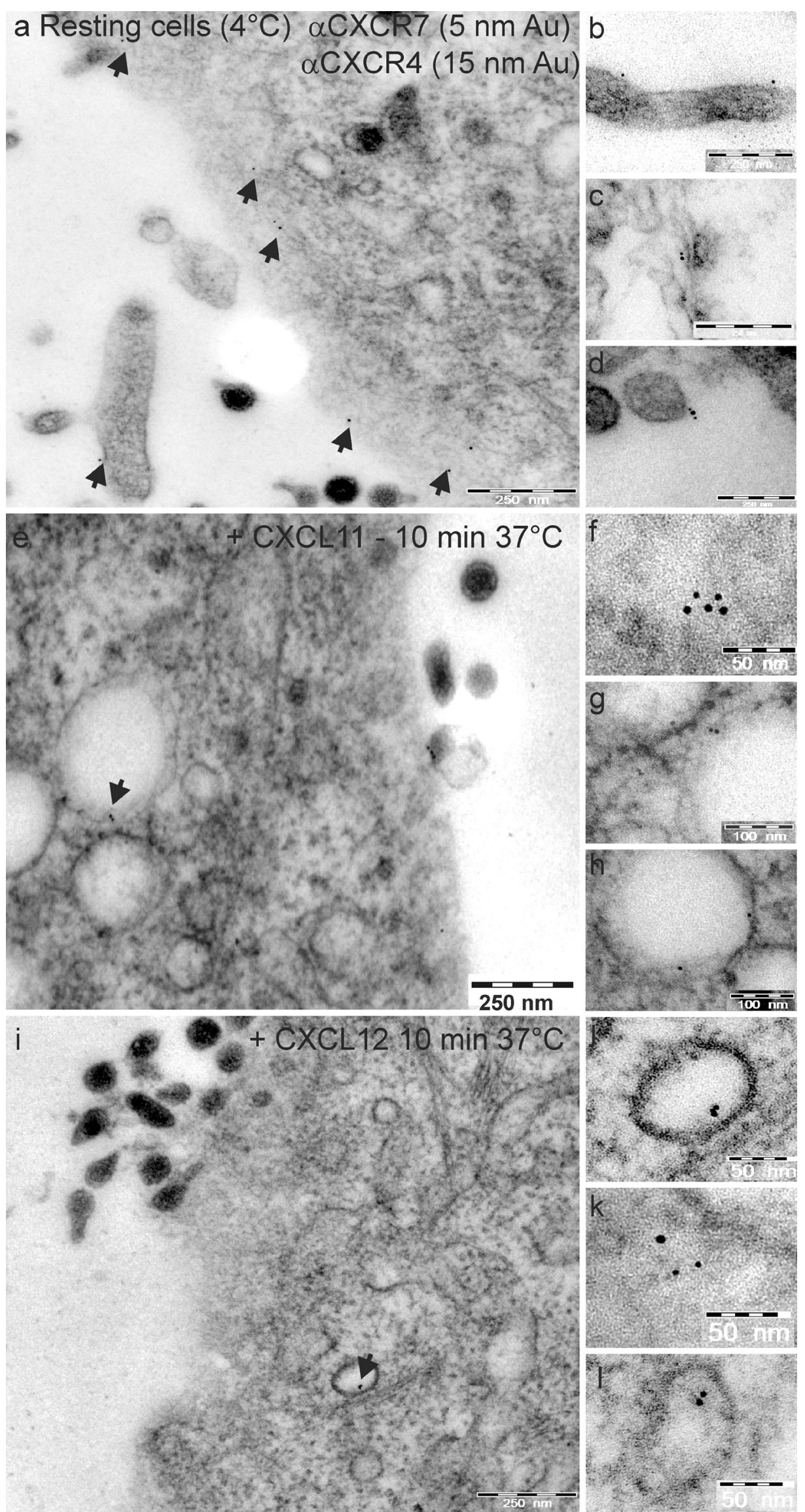
Fig. 4 Internalization of chemokine receptors CXCR4 and CXCR7 in MCF-7 cells upon stimulation with various ligands visualized by immuno-gold electron microscopy. CXCR4 was immuno-labeled by 15-nm gold particles and CXCR7 by smaller 5-nm gold particles at $4{ }^{\circ} \mathrm{C}$. Internalization was followed under stimulation with various ligands at various times at $37{ }^{\circ} \mathrm{C}$, as correspondingly described in Fig. 2 (arrowheads gold particles). a-d On resting cells, both labels were found on the cell surface mostly alone as single dots but also sometimes in close proximity as clusters of small and large dots. e-l Upon ligandinduced stimulation, receptors were internalized and found in intracellular vesicles. Here, they frequently accumulated in groups of dots of one or mixed sizes. This co-internalization was observed either with CXCL11 as the CXCR7-selective ligand (e-h) or with CXCL12 as the ligand for both receptors (i-I). To improve the visualization of the gold particles, sections were only weakly exposed to osmium tetroxide and lead citrate

After exposure to $37^{\circ} \mathrm{C}$, both receptors were rapidly internalized in the presence of ligands or antagonists and finally found in intracellular vesicles (Figs. 2, 3, 4). As seen best in immunofluorescence, CXCL12 stimulation initially resulted in a mostly separate internalization of both receptors $(5 \mathrm{~min}$, Fig. 2c, insert) as detected by separate red and green dots and a lower frequency of yellow (merged fluorescence) dots. However, after $10 \mathrm{~min}$, nearly all dots were intracellularly located (Fig. 2e). With CXCL11, which binds only to CXCR7, similar internalization kinetics were observed but co-internalization of the two receptors was somewhat delayed; namely, after $5 \mathrm{~min}$, red and green dots were located separately but at $10 \mathrm{~min}$, the images were mostly similar to those of CXCL12 (Fig. 2d, f).

Semi-quantification of receptor internalization was achieved by labeling the glycocalyx of the cell surface with WGA (a lectin that binds to sialic acid and $N$ acetyl-D-glucosamine) and determining the ratio of surface versus intracellular chemokine receptor fluorescence (Fig. 3; see Supplementary Fig. 1 for method).

Exposure of the receptor-labeled cells to selective nonpeptide antagonists AMD3100 or CCX733 (see Discussion) also yielded internalization of the receptors (Figs. 2g, h, 3e, f). Again, apart from receptor-selective internalization, namely CXCR4 by AMD3100 and CXCR7 by CCX733, cointernalization of the two receptors by their respective selective antagonist also occurred.

These results show that, on resting cells, both receptors are located at the cell surface alone or in close proximity. Upon stimulation with CXCL12 or CXCL11, rapid internalization of both chemokine receptors occurs. Furthermore, CXCR4 is also internalized by the CXCR7-ligand CXCL11 suggesting an interaction of both receptors. Not only exposure to ligands but also exposure to selective antagonists results in rapid receptor internalization. In addition to morphological connections, we next wanted to determine whether signal transductions and biological effects of both receptors were interconnected.
Signal transduction is initiated through both receptors by CXCL12 stimulation

When MCF-7 cells were stimulated with CXCL12, we observed phosphorylation of the kinases Erk1/2 in Western blots with a phosphorylation-specific antibody (Fig. 5). Phosphorylation could be significantly diminished by the receptor-selective non-peptide antagonists AMD3100 (for CXCR4) and by CCX733 (for CXCR7); each inhibitor induced no effects on its own (Fig. 5). These experiments show that stimulation by CXCL12 induces, in MCF-7 cells, a signal transduction that can be inhibited by receptor-selective non-peptide antagonists.

\section{CXCR4 and CXCR7 mediate apoptosis resistance}

To evaluate whether selective pharmacological inhibition also triggers combined biological effects, we measured anti-
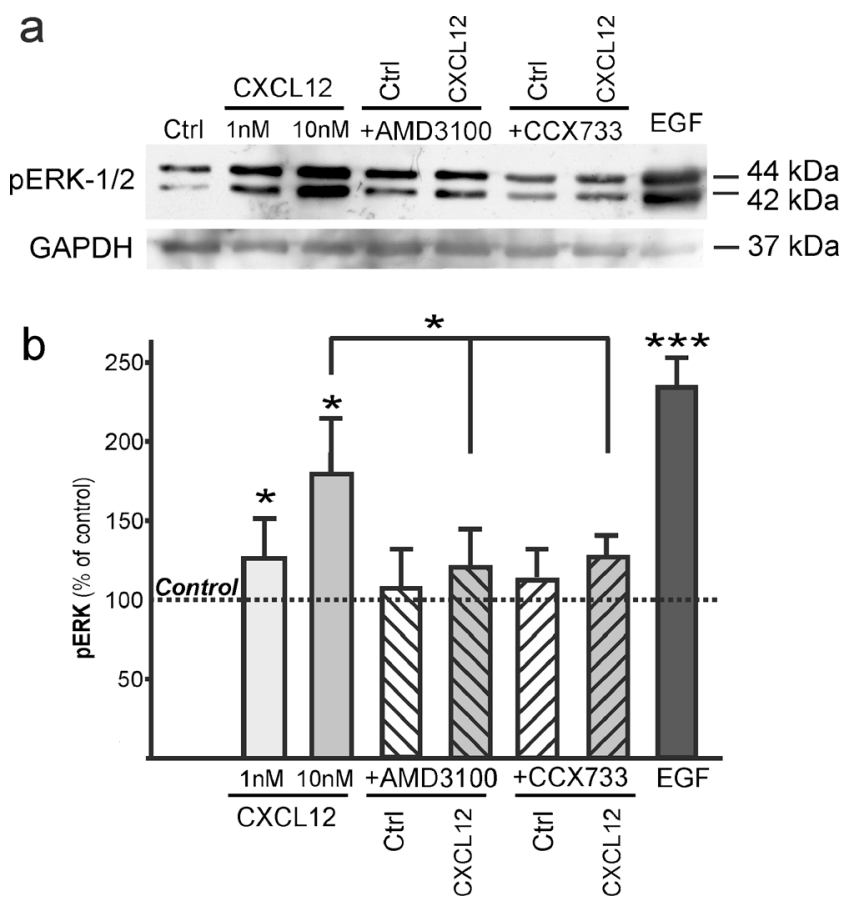

Fig. 5 Phosphorylation of the extracellular-signal-regulated kinases Erk1/2 (p42/p44) in MCF-7 cells upon stimulation with CXCL12 in the absence and presence of CXCR4- and CXCR7-specific antagonists ( $p E r k$ phosphorylated Erk, Ctrl control with antagonists alone). a, b Cells were stimulated for $15 \mathrm{~min}$ at $37{ }^{\circ} \mathrm{C}$ with ligand $(1$ or $10 \mathrm{nM})$, antagonists (AMD3100, $10 \mu \mathrm{M}$; CCX733, $0.1 \mu \mathrm{M}$ ), combinations, or a positive control $(10 \mathrm{ng} / \mathrm{ml}$ epidermal growth factor, $E G F)$, lysed and analyzed by Western blots probed with antibodies for the phosphorylated kinases and GAPDH (or re-probed for Erk2, not shown) to ensure equal loading. Example of several independent stimulations (top) and means \pm SD of densitometry of $n=5$ experiments (bottom). Stimulations were performed in serum-free media plus $0.1 \%$ bovine serum albumin on washed and 1-h-pre-equilibrated cells. The inhibitors were added from stock solutions in dimethylsulfoxide (DMSO, $0.1 \%$ final concentrations) at $1 \mathrm{~h}$ prior to the experiment; a corresponding amount of DMSO was added to all other cultures 


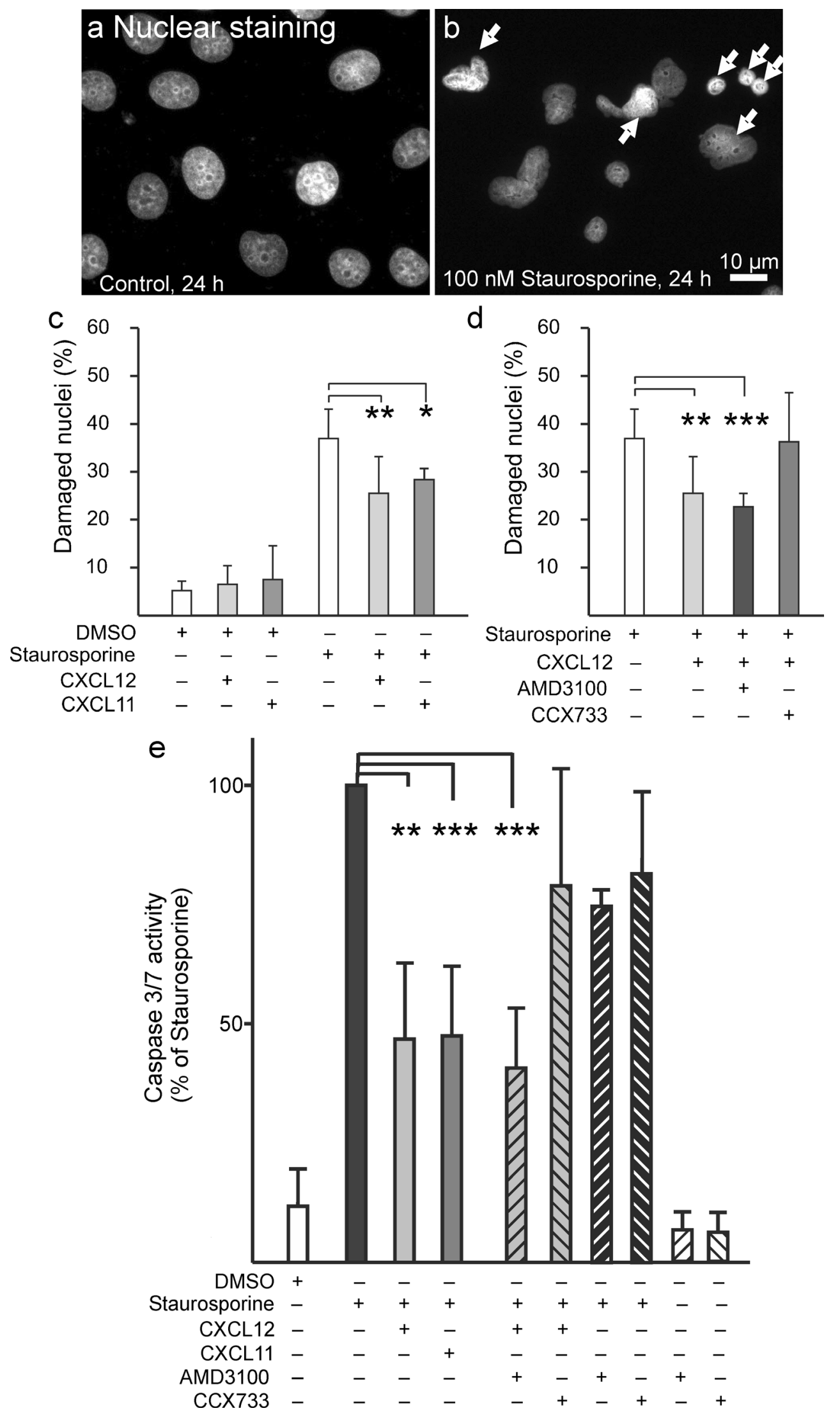


4 Fig. 6 Inhibition of staurosporine-induced apoptosis and caspase-3/7 activation by CXCL11 and CXCL12 in MCF-7 cells and influence of selective CXCR4 and CXCR7 inhibitors. Apoptosis was induced by 100 $\mathrm{nM}$ staurosporine in DMEM $+0.2 \% \mathrm{FCS}$ and analyzed by quantification of apoptotic nuclei after $24 \mathrm{~h}$ or by measurement of caspase-3/7-activity after $8 \mathrm{~h}$. a, b Visualisation of normal nuclei (a) and nuclei with signs of apoptosis (b, arrows nuclei damaged by fragmentation and/or chromatin condensation). $\mathbf{c}$ Both chemokine ligands, namely $5 \mathrm{nM} \mathrm{CXCL11} \mathrm{and} 1$ nM CXCL12, significantly reduced staurosporine-induced apoptosis. d This anti-apoptotic effect could be reversed by co-incubation with the CXCR7-selective antagonist CCX733 $(0.1 \mu \mathrm{M})$ but not significantly by CXCR4-selective antagonist AMD3100 $(5 \mu \mathrm{M})$. Both antagonists had no inhibitory effects on their own (not shown). Means of triplicate counting of several inspection areas from $n=4 \pm \mathrm{SD}$ individual stimulations by an unbiased person. e Corroborating the morphological results, both chemokine ligands, namely $5 \mathrm{nM}$ CXCL11 and $1 \mathrm{nM} \mathrm{CXCL12,}$ significantly reduced staurosporine-induced caspase-3/7 activation. Again, the antagonist CCX733 $(0.1 \mu \mathrm{M})$ but not AMD3100 $(5 \mu \mathrm{M})$, reduced this anti-apoptotic effect. Means of duplicate measurements from $n=3 \pm$ SD individual stimulations $(* P<0.05, * * P<0.01, * * * P<0.001)$. Antagonists showed neither effect on basal or staurosporine-induced capsase activities. Staurosporine and antagonists were added from stock solutions in DMSO yielding a final concentration of $0.5 \%$; therefore, corresponding amounts of DMSO were added to all other incubations

apoptotic effects previously preferentially attributed to CXCR7 (Hattermann et al. 2010). Apoptosis could be induced in MCF-7 cells by treatment with staurosporine. After $24 \mathrm{~h}$, about $40 \%$ of the cells showed apoptotic nuclei at a concentration of $100 \mathrm{nM}$ staurosporine (Fig. 6b, Supplementary Fig. 2). Co-incubation with both chemokines, CXCL11 or CXCL12, reduced apoptotic nuclei about $25 \%$ (Fig. 6c). The CXCL12-induced reduction of apoptosis could be inhibited by the CXCR7-selective antagonist CCX733 but not by the CXCR4-selective antagonist AM3100 (Fig. 6d). To corroborate these morphological findings by biochemical measurements, the activity of the effector caspases-3/7 was determined. After an 8-h exposure to $100 \mathrm{nM}$ staurosporine, caspase-3/7 activity was more than 10-fold higher than that of controls (Fig. 6e). Again, CXCL11 or CXCL12 efficiently reduced this increase by $40-50 \%$. Whereas the CXCR4antagonist AMD3100 did not influence CXCL12-induced apoptosis induction, the CXCR7-antagonist reduced the chemokine effect.

These experiments show that CXCL11 and CXCL12 both reduce chemically induced apoptosis. However, this anti-apoptotic effect is better inhibited by the CXCR7 antagonist.

\section{Discussion}

Among chemokine receptors, CXCR4 has been found to be most widely expressed in many types of tumors and has been shown to be involved in tumor cell invasion, metastasis, survival and proliferation (Müller et al. 2001; for a review, see Zlotnik et al. 2011). Reports on the occurrence and biological role of the newly discovered second receptor for the CXCR4-ligand CXCL12, namely CXCR7, in tumors are emerging (Burns et al. 2006; Miao et al. 2007; Wang et al. 2008; Hattermann et al. 2010; for a review, see Hattermann and Mentlein 2013). Few but often conflicting results have been published on the interaction of CXCR4 and CXCR7. Knowledge of the interactions between both CXCL12 receptors is of particular importance in tumor biology, because they are co-expressed on many tumor cells, including breast cancer cells and on tumor endothelial cells and tumor-associated macrophages (Miao et al. 2007; Hattermann et al. 2010; Heinrich et al. 2012). Since MCF-7 cells express both receptors at comparable levels, we used them as a model to investigate the internalization of CXCR4 and CXCR7 and to elucidate the biological effects of the common ligand CXCL12 or the specific CXCR7-ligand CXCL11 and during the application of selective antagonists.

By immunolabeling of intact cells, we were able to localize both receptors clearly at the cell surface by fluorescence and electron microscopy. This partly contrasts with a few reports that are based on immunocytochemistry of fixed cells and that claim a preferential intercellular localization of CXCR7 (Luker et al. 2010; Ray et al. 2012b). However, localization of CXCR7 has also been demonstrated at the cell surface (Kumar et al. 2012; Hattermann et al. 2012). Prelabeling of resting cells (without internalization, at $4{ }^{\circ} \mathrm{C}$ ) with antibodies has now clearly established the cell surface localization of both receptors. Culture conditions, e.g., serum content or pre-stimulation, might greatly influence localization at the cell surface or intracellularly. By means of immunofluorescence and electron-microscopy, we were also able to show that, upon stimulation, both receptors are internalized rapidly and in close contact. Our findings corroborate experiments with transfected HEK-293 cells investigated by bioluminescence resonance energy transfer, which revealed the heterodimerization of overexpressed CXCR4 and CXCR7 receptors (Levoye et al. 2009). Interestingly, stimulation with receptor-specific agonists and even with non-peptide antagonists results in pronounced co-internalization of the receptors.

Chemokine receptors are composed of about 340-370 amino acids with a short acidic N-terminal extracellular domain, seven helical transmembrane domains plus three intracellular and three extracellular hydrophilic loops and an intracellular $\mathrm{C}$-terminus containing serine and threonine residues that act as phosphorylation sites during receptor regulation (Allen et al. 2007). Receptor desensitization and internalization is achieved by agonist-dependent phosphorylation of the Cterminal tail, thereby promoting the binding of $\beta$-arrestins 
Fig. 7 Representation of CXCR4 and CXCR7 in human breast cancer cells upon stimulation with selective agonists or antagonists

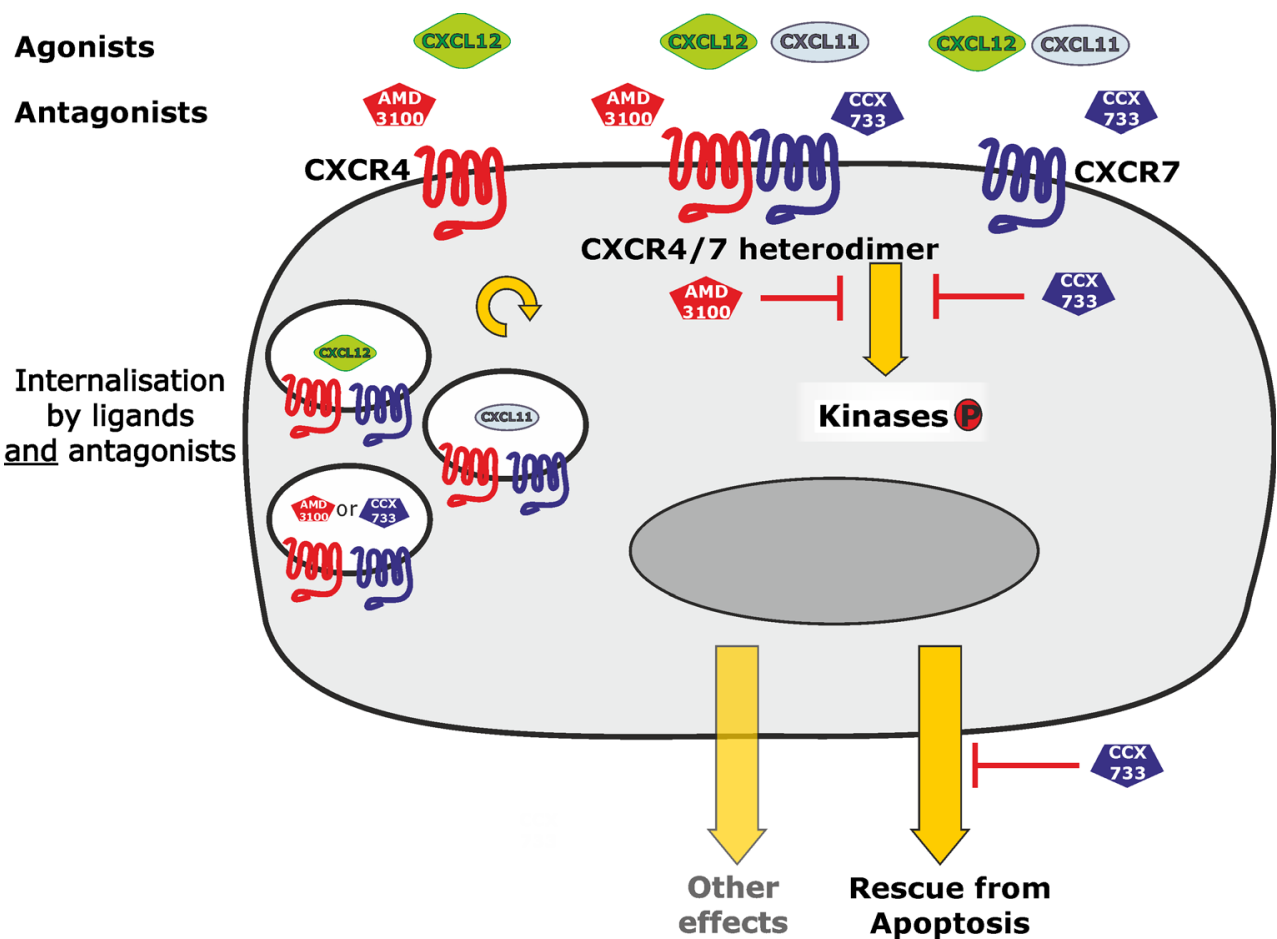

and internalization through clathrin-coated pits or lipid rafts/ caveolae (Canals et al. 2012). Stimulation of CXCR4 by CXCL12 is known to activate heterotrimeric G-proteins resulting in the dissociation of the $\mathrm{G} \alpha$ and $\mathrm{G} \beta \gamma$ subunits, which then activate downstream effectors (Busilo and Benovic 2007). A DRY-motif (DRYLAIV) in the second intracellular loop is thought to be essential for this Gprotein-mediated signaling. In contrast to CXCR4, CXCR7 lacks this domain and was initially regarded as a decoy receptor that regulates CXCL12 levels (Naumann et al. 2010). Nevertheless, recent studies have shown that CXCR7 can signal via an alternative pathway, namely via $\beta$-arrestins that are also involved in the internalization of G-protein-coupled receptors (Rajagopal et al. 2010; Ödemis et al. 2012; Luttrell et al. 2010). However, the issue of CXCR7 signaling is still controversial.

Based on our observations and previously reported coupled effects (Levoye et al. 2009; Ödemis et al. 2012), CXCR4CXCR7 heterodimers appear to be more distinct functional units than the receptors alone (Fig. 7). Dual activating effects on proliferation have been recently described in CXCR4CXCR7-coexpressing pancreatic cancer (Heinrich et al. 2012) or in Jurkat (Kumar et al. 2012) cells. As shown here, CXCL12-induced kinase phosphorylation in MCF-7 cells can be inhibited by selective agonists of one or the other receptor. In contrast, anti-apoptotic effects that are mediated by CXCL12 and CXCL11 alone are mainly antagonized by CCX733, the selective CXCR7 antagonist and not by AMD3100 antagonizing CXCR4. However, AMD3100 has been reported to act not solely as a simple CXCR4 antagonist (Kalatskaya et al. 2009). As measured by bioluminescence resonance energy transfer, AMD3100 also increases CXCL12 binding to CXCR7 and CXCL12-induced conformational rearrangements in the receptor dimer. Moreover, small increases in the potency of CXCL12-induced arrestin recruitment to CXCR7 by AMD3100 have been observed (Kalatskaya et al. 2009).

Thus, heterodimerization influences not only receptor internalization but also signal transduction and biological effects. Moreover, the pharmacological profiles of specific inhibitors are changed, as shown in our study.

Overall, the CXCL12-CXCR4-CXCR7-axis is highly complex. The bioavailability of CXCL12 (and CXCL11) is controlled by ligand dimerization (Ray et al. 2012a), by binding to heparan sulfate glycosaminoglycans on the cell surface (Allen et al. 2007), by proteolytic degradation (Ludwig et al. 2002; Mentlein 2004) and by receptor-mediated internalization (as shown here). Biological effects depend on the receptor subtype expressed by the particular cell type and on receptor interactions, if both subtypes are expressed.

Acknowledgements We thank Judith Becker, Martina Burmester, Sonja Dahle, Marion Kölln, Miriam Lemmer and Kathrin NeblungMasuhr for expert technical assistance and Clemens Franke for drawing the relevant figures. Mark E.T. Penfold and Thomas J. Schall (ChemoCentryx, Mountain View, Calif., USA) generously provided CXCR7 antibodies and antagonists; Udo Schumacher 
(Anatomy, University of Hamburg, Germany) supplied us with tumor cell lines.

Open Access This article is distributed under the terms of the Creative Commons Attribution License, which permits any use, distribution and reproduction in any medium, provided the original author(s) and the source are credited.

\section{References}

Allen SJ, Crown SE, Handel TM (2007) Chemokine: receptor structure, interactions, and antagonism. Annu Rev Immunol 25:787-820

Balabanian K, Lagane B, Infantino S, Chow KY, Harriague J, Moepps B, Arenzana-Seisdedos F, Thelen M, Bachelerie F (2005) The chemokine SDF-1/CXCL12 binds to and signals through the orphan receptor RDC1 in T lymphocytes. J Biol Chem 280:35760-35766

Burns JM, Summers BC, Wang Y, Melikian A, Berahovich R, Miao Z, Penfold ME, Sunshine MJ, Littman DR, Kuo CJ, Wei K, McMaster BE, Wright K, Howard MC, Schall TJ (2006) A novel chemokine receptor for SDF-1 and I-TAC involved in cell survival, cell adhesion, and tumor development. J Exp Med 203:2201-2213

Busillo JM, Benovic JL (2007) Regulation of CXCR4 signaling. Biochim Biophys Acta 1768:952-963

Canals M, Scholten DJ, de Munnik S, Han MK, Smit MJ, Leurs R (2012) Ubiquitination of CXCR7 controls receptor trafficking. PLoS One 7:e34192

Décaillot FM, Kazmi MA, Lin Y, Ray-Saha S, Sakmar TP, Sachdev P (2011) CXCR7/CXCR4 heterodimer constitutively recruits betaarrestin to enhance cell migration. J Biol Chem 286:32188-32197

Hattermann K, Mentlein R (2013) An infernal trio: the chemokine CXCL12 and its receptors CXCR4 and CXCR7 in tumor biology. Ann Anat 195:103-110

Hattermann K, Ludwig A, Gieselmann V, Held-Feindt J, Mentlein R (2008) The chemokine CXCL16 induces migration and invasion of glial precursor cells via its receptor CXCR6. Mol Cell Neurosci 39:133-141

Hattermann K, Held-Feindt J, Lucius R, Sebens Müerköster S, Penfold ME, Schall TJ, Mentlein R (2010) The chemokine receptor CXCR7 is highly expressed in human glioma cells and mediates antiapoptotic effects. Cancer Res 70:3299-3308

Hattermann K, Held-Feindt J, Mentlein R (2012) CXCL12 mediates apoptosis resistance in rat C6 glioma cells. Oncol Rep 27:13481352

Heinrich EL, Lee W, Lu J, Lowy AM, Kim J (2012) Chemokine CXCL12 activates dual CXCR4 and CXCR7-mediated signaling pathways in pancreatic cancer cells. J Transl Med 10:68

Hernandez L, Magalhaes MA, Coniglio SJ, Condeelis JS, Segall JE (2011) Opposing roles of CXCR4 and CXCR7 in breast cancer metastasis. Breast Cancer Res 13:R128

Kalatskaya I, Berchiche YA, Gravel S, Limberg BJ, Rosenbaum JS, Heveker N (2009) AMD3100 is a CXCR7 ligand with allosteric agonist properties. Mol Pharmacol 75:1240-1247

Krisch B, Feindt J, Mentlein R (1998) Immunoelectron microscopic analysis of the ligand-induced internalization of the somatostatin receptor subtype 2 in cultured human glioma cells. J Histochem Cytochem 46:1233-1242

Kumar R, Tripathi V, Ahmad M, Nath N, Mir RA, Chauhan SS, Luthra K (2012) CXCR7 mediated Gi $\alpha$ independent activation of ERK and
Akt promotes cell survival and chemotaxis in T cells. Cell Immunol 272:230-241

Lange A, Gustke H, Glassmeier G, Heine M, Zangemeister-Wittke U, Schwarz JR, Schumacher U, Lange T (2011) Neuronal differentiation by indomethacin and IBMX inhibits proliferation of small cell lung cancer cells in vitro. Lung Cancer 74:178-187

Levoye A, Balabanian K, Baleux F, Bachelerie F, Lagane B (2009) CXCR7 heterodimerizes with CXCR4 and regulates CXCL12mediated $G$ protein signaling. Blood 113:6085-6093

Ludwig A, Schiemann F, Mentlein R, Lindner B, Brandt E (2002) Dipeptidyl peptidase IV (CD26) on T cells cleaves the CXC chemokine CXCL11 (I-TAC) and abolishes the stimulating but not the desensitzing potential of the chemokine. J Leucocyte Biol 72:183-191

Ludwig A, Schulte A, Schnack C, Hundhausen C, Reiss K, Brodway N, Held-Feindt J, Mentlein R (2005) Enhanced expression and shedding of the transmembrane chemokine CXCL16 by reactive astrocytes and glioma cells. J Neurochem 93:1293-1303

Luker KE, Steele JM, Mihalko LA, Ray P, Luker GD (2010) Constitutive and chemokine-dependent internalization and recycling of CXCR7 in breast cancer cells to degrade chemokine ligands. Oncogene 29: 4599-4610

Luttrell LM, Gesty-Palmer D (2010) Beyond desensitization: physiological relevance of arrestin-dependent signaling. Pharmacol Rev 62: 305-330

Mentlein R (2004) Cell-surface peptidases. Int Rev Cytol 235:165-213

Mentlein R, Held-Feindt J (2002) Pleiotrophin, an angiogenic and mitogenic growth factor, is expressed in human gliomas. J Neurochem 83:747-753

Mentlein R, Hattermann K, Held-Feindt J (2013) Migration, metastasis and more: the role of chemokines in the proliferation, spreading and metastasis of tumors. In: Resende RR, Ulrich H (eds) Trends in stem cell proliferation and cancer research. Springer, Dordrecht, pp 339-358

Miao Z, Luker KE, Summers BC, Berahovich R, Bhojani MS, Rehemtulla A, Kleer CG, Essner JJ, Nasevicius A, Luker GD, Howard MC, Schall TJ (2007) CXCR7 (RDC1) promotes breast and lung tumor growth in vivo and is expressed on tumor-associated vasculature. Proc Natl Acad Sci U S A 104:15735-15740

Müller A, Homey B, Soto H, Ge N, Catron D, Buchanan ME, McClanahan T, Murphy E, Yuan W, Wagner SN, Barrera JL, Mohar A, Verástegui E, Zlotnik A (2001) Involvement of chemokine receptors in breast cancer metastasis. Nature 410:50-56

Naumann U, Cameroni E, Pruenster M, Mahabaleshwar H, Raz E, Zerwes HG, Rot A, Thelen M (2010) CXCR7 functions as a scavenger for CXCL12 and CXCL11. PLoS One 5:e9175

Nicoletti I, Migliorati G, Pagliacci MC, Grignani F, Riccardi C (1991) A rapid and simple method for measuring thymocyte apoptosis by propidium iodide staining and flow cytometry. J Immunol Methods 139:271-279

Ödemis V, Lipfert J, Kraft R, Hajek P, Abraham G, Hattermann K, Mentlein R, Engele J (2012) The presumed atypical chemokine receptor CXCR7 signals through $\mathrm{G}(\mathrm{i} / \mathrm{o})$ proteins in primary rodent astrocytes and human glioma cells. Glia 60:372-381

Rajagopal S, Kim J, Ahn S, Craig S, Lam CM, Gerard NP, Gerard C, Lefkowitz RJ (2010) Beta-arrestin - but not G protein-mediated signaling by the "decoy" receptor CXCR7. Proc Natl Acad Sci U S A 107:628-632

Ray P, Lewin SA, Mihalko LA, Lesher-Perez SC, Takayama S, Luker KE, Luker GD (2012a) Secreted CXCL12 (SDF-1) forms dimers under physiological conditions. Biochem J 442:433-442

Ray P, Mihalko LA, Coggins NL, Moudgil P, Ehrlich A, Luker KE, Luker GD (2012b) Carboxy-terminus of CXCR7 regulates receptor localization and function. Int $\mathrm{J}$ Biochem Cell Biol 44:669-678 
Sánchez-Alcañiz JA, Haege S, Mueller W, Pla R, Mackay F, Schulz S, López-Bendito G, Stumm R, Marín O (2011) Cxcr7 controls neuronal migration by regulating chemokine responsiveness. Neuron 69:77-90

Stark A, Anuszkiewicz B, Mentlein R, Yoneda T, Mehdorn HM, HeldFeindt J (2007) Differential expression of matrix metalloproteinases in brain- and bone-seeking clones of metastatic MDA-MB-231 breast cancer cells. J Neurooncol 81:39-41

Thelen M, Thelen S (2008) CXCR7, CXCR4 and CXCL12: an eccentric trio? J Neuroimmunol 198:9-13

Thies A, Mauer S, Fodstad O, Schumacher U (2007) Clinically proven markers of metastasis predict metastatic spread of human melanoma cells engrafted in SCID mice. Br J Cancer 96: 609-616

Wang J, Shiozawa Y, Wang J, Shiozawa Y, Wang J, Wang Y, Jung Y, Pienta KJ, Mehra R, Loberg R, Taichman RS (2008)
The role of CXCR7/RDC1 as a chemokine receptor for CXCL12/SDF-1 in prostate cancer. J Biol Chem 283:42834294

Yan X, Cai S, Xiong X, Sun W, Dai X, Chen S, Ye Q, Song Z, Jiang Q, Xu Z (2012) Chemokine receptor CXCR7 mediates human endothelial progenitor cells survival, angiogenesis, but not proliferation. J Cell Biochem 113:1437-1446

Zabel BA, Wang Y, Lewén S, Berahovich RD, Penfold ME, Zhang P, Powers J, Summers BC, Miao Z, Zhao B, Jalili A, JanowskaWieczorek A, Jaen JC, Schall TJ (2009) Elucidation of CXCR7mediated signaling events and inhibition of CXCR4-mediated tumor cell transendothelial migration by CXCR7 ligands. J Immunol 183: 3204-3211

Zlotnik A, Burkhardt AM, Homey B (2011) Homeostatic chemokine receptors and organ-specific metastasis. Nat Rev Immunol 11: 597-606 